\title{
PENGARUH LINGKUNGAN KERJA DAN STRES KERJA TERHADAP KINERJA KARYAWAN RSPAD GATOT SOEBROTO (STUDI PADA KARYAWAN RSPAD GATOT SOEBROTO DI JAKARTA)
}

\author{
Anggita Trisia Nauli, Loeky Rono Pradopo \\ Sekolah Tinggi Ilmu Ekonomi Jayakarta \\ anggitatrisia@gmail.com, loekyrp@yahoo.co.id
}

\begin{abstract}
ABSTRAK
Pengaruh Lingkungan Kerja dan Stres Kerja Terhadap Kinerja Karyawan RSPAD Gatot Soebroto. Oleh Anggita Trisia Nauli, NIM : 14252002.

Kata Kunci: Lingkungan kerja, stres kerja, kinerja karyawan.

Penelitian ini bertujuan untuk mengetahui pengaruh lingkungan kerja dan stres terhadap kinerja bagi karyawan operasional pada RSPAD Gatot Soebroto. Dimana diajukan dua variabel bebas dan satu variabel terikat, yaitu lingkungan kerja dan stres kerja berperan sebagai variabel bebas dan kinerja karyawan berperan sebagai variabel terikat.

Penilitian ini dilakukan dengan metode survey terhadap karyawan RSPAD Gatot Soebroto dianalisis dengan regresi. Tahap pertama menguji validitas dan reliabilitas pertanyaan setiap variabel. Tahap kedua, meregresi variabel lingkungan kerja dan stres kerja terhadap kinerja karyawan.

Hasil penelitian menunjukkan bahwa variabel lingkungan kerja berpengaruh positif signifikan terhadap kinerja karyawan di tolak. Serta variabel stres kerja berpengaruh negatif signifikan terhadap kinerja karyawan di tolak. Namun demikian, stres kerja yang berada pada tingkat rendah sampai sedang akan menciptakan kinerja karyawan yang baik dan akan memperburuk karyawan jika dalam tempo waktu yang sangat lama dan berlebihan.
\end{abstract}

\section{ABSTRACT}

The influence of work environment and job stress on employee performance of RSPAD Gatot Soebroto. by Anggita Trisia Nauli NIM 14252002.

Keywords : Work environment, job stress, employee performance

This study aims to determine the effect of work environment and stress on performance for operational employees at RSPAD Gatot Soebroto. Where the proposed two independent variables and one 
dependent variable, namely the working environment and job stress acting as independent variables and employee performance served as dependent variables.

This research was conducted using a survey of operational employees in the RSPAD Gatot Soebroto was analyzed by regression. The first phase of testing the validity and reliability of questions of each variable. The second phase, making the regression variable work environment and work stress on employee performance.

The results showed that the variable has a significant positive work environment on the performance of employees in decline. And work stress variables significant negative effect on employee performance in decline. However, work stress are at low to moderate level will create a good employee performance and will worsen if the employee within a very long time and excessive. 


\section{PENDAHULUAN}

\section{A. Latar Belakang Penelitian}

Manajemen sumber
daya manusia (MSDM)
merupakan bagian dari
manajemen keorganisasian yang memfokuskan diri pada unsur sumber daya manusia. Di dalam organisasi, manusia merupakan salah satu unsur yang terpenting didalam suatu organisasi. Tanpa peran manusia meskipun berbagai faktor yang dibutuhkan itu telah tersedia, organisasi tidak akan berjalan. Karena manusia merupakan penggerak dan penentu jalannya suatu organisasi. Oleh karena itu, hendaknya organisasi memberikan arahan yang positif demi tercapainya tujuan organisasi.

$$
\text { Salah satu faktor }
$$

yang memengaruhi tingkat Usaha untuk

meningkatkan kinerja karyawan, di antaranya adalah dengan memerhatikan stres kerja. Stres merupakan suatu kondisi keadaan seseorang mengalami ketegangan karena adanya kondisi yang

Selain stres, faktor lain yang memengaruhi kinerja karyawan adalah lingkungan kerja. Lingkungan kerja merupakan segala sesuatu yang ada disekitar keberhasilan suatu organisasi adalah kinerja karyawannya. Kinerja karyawan merupakan suatu tindakan yang dilakukan karyawan dalam melaksanakan pekerjaan yang diberikan perusahaan. Dengan memiliki karyawan yang berprestasi perusahaan dapat meningkatkan kinerja perusahaannya. Apabila individu dalam perusahaan, yaitu SDM-nya dapat berjalan efektif maka perusahaan tetap berjalan efektif. Dengan kata lain, kelangsungan suatu perusahaan itu ditentukan oleh kinerja karyawannya. Kinerja karyawan dipengaruhi oleh beberapa faktor yaitu : gaji, lingkungan kerja, budaya organisasi, kepemimpinan dan motivasi kerja (motivation), disiplin kerja, kepuasan kerja, komunikasi dan faktor-faktor lainnya.

mempengaruhinya, kondisi tersebut dapat diperoleh dari dalam diri seseorang maupun lingkungan di luar diri seseorang. Stres dapat menimbulkan dampak yang negatif terhadap keadaan psikologis dan biologis bagi karyawan.

para pekerja yang dapat memengaruhi dirinya dalam mejalankan tugas-tugas yang dibebankan, misalnya kebersihan, musik dan sebagainya. Dalam mencapai 
kenyamanan tempat kerja antara lain dapat dilakukan dengan jalan memelihara prasarana fisik seperti seperti kebersihan yang selalu terjaga, penerangan cahaya yang cukup, ventilasi udara, suara musik dan tata ruang kantor yang nyaman. Kondisi Penelitian ini mengambil objek penelitian pada RSPAD Gatot Soebtoro yang merupakan perusahaan bergerak di bidang jasa kesehatan. Kegiatan yang dilakukan RSPAD Gatot Soebroto adalah dalam menangani pasien maupun berkas-berkas yang berhubungan dengan pasien misalnya asuransi dan pembayaran tunai. Maka RSPAD Gatot Soebroto sangat membutuhkan kinerja karyawan yang tinggi untuk meningkatkan produktivitas rumah sakit dalam menangani pasien, karena dengan memiliki tanggung jawab yang tinggi, tujuan yang realitas, rencana kerja yang menyeluruh, berani mengambil risiko yang dihadapai, maka produktivitas akan meningkat, oleh karena itu salah satunya adalah dengan meminimalisir stres kerja dan menciptakan lingkungan kerja yang baik serta kondusif.

Oleh karena itu, berdasarkan pernyataanpernyataan di atas, maka penulis tertarik untuk seperti inilah yang selanjutnya menciptakan antusiasme untuk bersatu dalam organisasi perusahaan untuk mencapai tujuan perusahaan denga meningkatkan kinerja karyawan.

mengadakan penelitian dengan judul: "Pengaruh Lingkungan Kerja dan Stres Kerja terhadap Kinerja Karyawan pada RSPAD Gatot Soebroto".

\section{B. Perumusan Masalah}

Berdasarkan latar belakang yang dikemukakan di atas, maka secara terperinci masalah yang akan diteliti adalah lingkungan kerja yang berada di sekitar rumah sakit dapat berpengaruh pada kinerja karyawan dan kondisi stres kerja karyawan yang berpengaruh pada kinerja karyawan.

Dari masalah di atas maka dapat diperoleh rumusan masalah sebagai berikut:

1. Bagaimana kategori
lingkungan kerja pada
RSPAD Gatot Soebroto?

2. Bagaimana kategori tingkat stres kerja pada RSPAD Gatot Soebroto?

3. Bagaimana kategori kinerja kerja pada RSPAD gatot Soebroto?

4. Apakah lingkungan kerja dapat memengaruhi kinerja karyawan pada 


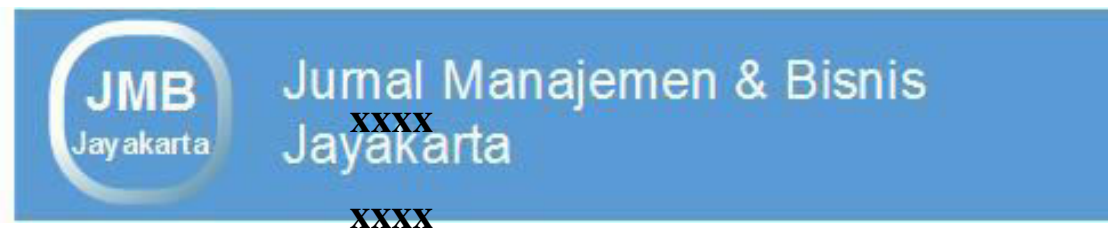

p-ISSN : $\mathbf{x x x x -}$

e-ISSN : $x x x x-$

Juli 2019

Vol. 01, No. 1,

RSPAD Gatot Soebroto?

5. Apakah stres kerja dapat memengaruhi kinerja karyawan pada RSPAD Gatot Soebroto?

6. Apakah lingkungan kerja dan stres kerja secara simultan dapat memengaruhi kinerja karyawan?

\section{Tujuan Penelitian}

Tujuan penelitian yang

dilakukan pada karyawan RSPAD

Gatot Soebroto adalah sebagai berikut:

1. Untuk menganalisis kategori lingkungan kerja pada RSPAD Gatot Soebroto.

2. Untuk menganalisis kategori tingkat stres kerja pada RSPAD Gatot Soebroto.

3. Untuk menganalisis kategori kinerja kerja pada RSPAD gatot Soebroto.

4. Untuk mengetahui pengaruh lingkungan kerja terhadap kinerja karyawan pada RSPAD Gatot Soebroto.

5. Untuk mengetahui pengaruh stres kerja terhadap kinerja karyawan pada RSPAD Gatot Soebroto.

6. Untuk mengetahui pengaruh lingkungan kerja dan stres kerja terhadap kinerja karyawan RSPAD Gatot Soebroto.

\section{KAJIAN LITERATUR}

\section{A. Kinerja Kayawan}

Definisi operasional kinerja karyawan adalah hasil kerja yang dapat dicapai oleh seorang karyawan atau kelompok karyawan dalam suatu instansi/dinas di lingkungannya sesuai dengan wewenang dan tanggung jawab masing-masing, dalam upaya pencapaian tujuannya secara legal, tidak melanggar hukum dan tidak bertentangan dengan moral atau etika.

\section{B. Lingkungan Kerja}

Lingkungan kerja adalah kehidupan sosial, psikologi, dan fisik dalam perusahaan yang berpengaruh terhadap pekerja dalam melaksanakan tugasnya.

Selama melakukan pekerjaan, setiap pegawai akan berinteraksi dengan berbagai kondisi yang terdapat dalam lingkungan kerja. Kinerja karyawan dipengaruhi oleh banyak faktor diantaranya adalah jumlah komposisi dari kompensasi yang diberikan, penempatan yang tepat, latihan, rasa aman di masa depan mutasi promosi.

C. Stres Kerja

Stress kerja adalah kondisi ketegangan yang berpengaruh pada emosi, jalan pikiran, dan kondisi fisik seseorang dalam melakukan pekerjaan, suatu perasaan yang menekan atau rasa tertekan yang dialami karyawan dalam menghadapi pekerjaannya.

Setiap aspek di pekerjaan dapat menjadi pembangkit stres.Tenaga kerja yang menentukan sejauh mana situasi yang dihadapi merupakan situasi stres atau tidak. Tenaga kerja dalam interaksinya dipekerjaan, dipengaruhi pula oleh hasil interaksi di tempat lain, di rumah, di sekolah, di perkumpulan, dan sebagainya.

D. Kerangka Pemikiran

$\mathrm{Di}$ dalam perusahaan diperlukan adanya kinerja yang tinggi untuk meningkatkan mutu dan 
kualitas produktivitasnya.

Kinerja merupakan hasil kerja secara kualitas dan kuantitas yang dicapai oleh seorang karyawan dalam melaksanakan tugasnya sesuai dengan tanggung jawab yang diberikan kepadanya. Oleh karena itu, supaya kinerja karyawan itu bisa meningkat, maka perusahaan juga harus memerhatikan tentang lingkungan kerja dan stres kerja karyawan karena sangat memengaruhi kinerja karyawannya.

Lingkungan kerja sangat berpengaruh besar untuk meningkatkan kinerja karyawan, sehingga akan mendorong semangat kerja. Semangat kerja tersebut sangat dibutuhkan karyawan dalam rangka meningkatkan kinerjanya.

Stres kerja adalah suatu bentuk tanggapan seseorang, baik fisik maupun mental terhadap suatu perubahan di lingkungannya yang dirasakan mengganggu dan mengakibatkan dirinya terancam.

Berpijak dari pemikiran di atas, maka dapat digambarkan sebuah kerangka pemikiran, sebagai berikut: deskriptif dan penelitian eksplanatif bertujuan untuk memberi gambaran tentang suatu masyarakat atau suatu kelompok orang tertentu atau gambaran tentang suatu gejala atau hubungan antara dua gejala atau lebih.

Penelitian deskriptif adalah akumulasi data dasar dalam cara deskriptif semata-mata tidak perlu mencari, atau menerangkan saling berhubungan, menguji hipotesis, membuat ramalan atau mendapatkan makna dan implikasi.

$$
\text { Sedangkan penelitian }
$$

eksplanatif adalah jenis penelitian yang bertujuan untuk menemukan penjelasan tentang mengapa suatu kejadian atau gejala terjadi. Serta untuk menguji hipotesis dan mejelaskan hubungan variabel penelitian. Hasil akhir dari penelitian ini adalah gambaran mengenai hubungan sebab akibat.

\section{B. Teknik Analisis Data}

Berikut paparan teknik analisis yang dipakai dalam pengolahan data yang ada guna mendapatkan kesimpulan dari penelitian ini, yaitu sebagai berikut:

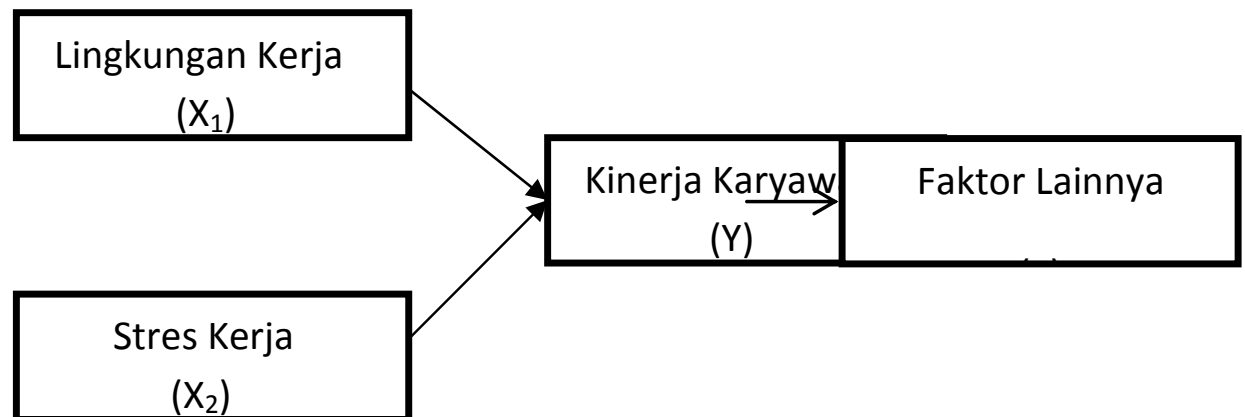

\section{Gambar Kerangka Pemikiran}

\section{METODE PENELITIAN}

\section{A. Jenis Penelitian}

Berdasarkan tujuan jenis penelitian yang digunakan dalam penelitian ini adalah penelitian
1. Uji Validitas

Validitas suatu instrumen berkaitan dengan kemampuan instrumen itu mengukur atau mengungkap karakteristik dari variabel yang dimaksudkan untuk diukur. 
Perhitungan korelasi dilakukan dengan menggunakan bantuan software SPSS versi 20. jika hasil koefesien korelasi suatu pertanyaan dengan nilai $>0,3$ maka pertanyaan dapat digunakan untuk analisis data, sedangkan jika nilai koefesien korelasi $<0,30$ maka pertanyaan tidak dapat digunakan untuk bahan analisis data.

2. Uji Reliabilitas

Reliabilitas adalah sejauh mana hasil suatu pengukuran dapat dipercaya,

Tujuan perhitungan adalah untuk mengetahui tingkat konsistensi jawaban responden. Sedangkan untuk menguji reliabilitas instrumen digunakan koefisien reliability Alpha Cronbach.

3. Analisis Prediksi Rata-Rata Skor. Untuk keperluan analisi data, masing-masing alternatif jawaban tersebut diberi nilai skor. Alternatif jawaban yang terbaik atau jawaban yang sangat diharapkan peneliti, diberikan nilai dengan skor tertinggi atau angka 5 , dan yang terburuk diberikan skor terendah atau angka 1 untuk menentukan prediksi skor ratarata dari hasil jawaban responden digunakan rumus:

$$
\bar{M}=\frac{\sum(\mathrm{FS})}{n}
$$

Untuk mengetahui ratarata skor dari jawaban responden harus menentukan interval kelas skor dari setiap kategori yang menggunakan rumus:

$$
C I=\frac{\text { Range }}{c}
$$

4. Analisis Regresi Berganda

Analisis regresi berganda yaitu untuk mengukur seberapa jauh pengaruh lingkungan kerja, stres kerja, terhadap kinerja karyawan dengan analisis yang digunakan analisa regresi linear berganda

$$
\text { dapat dirumuskan }
$$

sebagai berikut:

$$
Y_{1}=a+b_{1} X_{1}+b_{2} X_{2}
$$

5. Analisis Koefisien Korelasi

Untuk menguji hipotesis ini digunakan uji statistik noparametric, yaitu korelasi "Rank Spearman" untuk melihat hubungan antara variabel lingkungan kerja, stres kerja dan terhadap kinerja karyawan.

Rumus korelasi "Rank Spearman" yang digunakan dalam hal ini sebagai berikut:

$$
r s=1-\frac{6 \sum \mathrm{d}^{2}}{n\left(n^{2}-1\right)}
$$

6. Analisis Hipotesis dengan Uji $t$ (Pengaruh secara Parsial)

Uji statistik $t$ pada dasarnya menunjukkan seberapa jauh pengaruh satu variabel penjelas secara individual dalam menerangkan variasi variabel terikat. Rumus yang digunakan untuk menguji hipotesis tersebut adalah:

$$
t \text { hitung }=\frac{\mathbf{r s} \sqrt{\mathbf{n}-2}}{\sqrt{\mathbf{1 - \mathbf { r s 2 }}}}
$$

7. Analisis Hipotesis dengan Uji $F$ (Pengaruh secara serempak)

Uji $F$ digunakan untuk menentukan apakah secara serentak variabel independen mampu menjelaskan variabel dependen dengan baik atau apakah variabel independen mempunyai pengaruh yang signifikan terhadap variabel dependen secara bersama-sama. Rumus yang digunakan untuk 
menguji hipotesis tersebut adalah:

$$
F \text { hitung }=\frac{R^{2}(k-1)}{\left(1-R^{2}\right) /(N-k)}
$$

8. Analisis Koefisien Determinasi

Untuk melihat seberapa besar tingkat pengaruh variabel independen terhadap variabel dependen secara parsial digunakan koefisien determinasi (KD) dengan rumus menurut Sugiyono (2012: 257) sebagai berikut:

$$
K D=r^{2} \times 100 \%
$$

\section{HASIL PENELITIAN DAN PEMBAHASAN}

\section{A. Deskripsi Objek Penelitian}

Penelitian ini dilakukan oleh peneliti dengan cara mengajukan kuesioner kepada responden yang berjumlah 100 orang yang diambil secara random. Kuesioner ini terdiri dari 30 butir pertanyaan yang mewakili 3 variabel yang diteliti. Ketiga variabel penelitian yang berbentuk kuesioner ini adalah variabel lingkungan kerja $\left(X_{1}\right)$, stres kerja $\left(X_{2}\right)$, dan variabel kinerja karyawan $(\mathrm{Y})$ terhadap para pekerja di RSPAD Gatot Soebroto.

\section{B. Deskripsi Responden}

Berikut adalah deskripsi data responden yang merupakan hasil identifikasi berdasarkan jenis kelamin,pekerjaan, dan pendidikan terakhir.

\section{Deskripsi Data Berdasarkan Jenis Kelamin}

Hasil penelitian berdasarkan jenis kelamin dengan seluruh responden, dalam penelitian ini adalah berjenis kelamin pria sebanyak 49 orang dan yang berjenis wanita sebanyak 51 orang, total keseluruhan responden sebanyak 100 orang (100 $\%)$.

\section{Deskripsi Data Berdasarkan Pekerjaan}

Responden berdasarkan pekerjaan tenaga medis sebanyak 25 orang (25\%), Farmasi 25 orang (25 $\%)$, Pengamanan 25 orang (25\%), dan staf administrasi 25 orang (25\%).

\section{Deskripsi Data Berdasarkan Pendidikan \\ Responden berdasarkan} pendidikan terakhir SMA sebanyak 26orang (26\%), Diploma 41 orang (41 $\%$ ), dan Sarjana 33 orang (33\%).

\section{Deskripsi Data Berdasarkan Usia}

Responden berdasarkan usia kurang dari 20 tahun sebanyak 17orang (17 \%), 20 tahun sampai dengan 29 tahun 35 orang (35\%), 30 tahun sampai dengan 39 tahun 31 orang $(31 \%)$, dan lebih dari 40 tahun 17 orang $(17 \%)$.

\section{Hasil Analisis Data Statistik Deskriptif}

\section{Analisis Prediksi Rata-rata Skor}

a. Dimensi Variabel Lingkungan Kerja $\left(\mathbf{X}_{1}\right)$

Dengan dimensi variabel ini dipaparkan untuk masingmasing indikator dari dimensi variabel lingkungan kerja dengan hasil prediksi rata-rata skor.

Nilai prediksi rata-rata skor variabel lingkungan kerja sebesar 4,281. Nilai 4,281 masuk dalam rentang 4,20-5,00, berarti dimensi variabel lingkungan kerja dikategorikan sangat baik atau rata-rata responden menyatakan sangat setuju.

b. Dimensi Variabel Stres Kerja $\left(X_{2}\right)$

Terlihat nilai prediksi ratarata skor variabel stres kerja 
sebesar 3,309. Nilai 3,309 masuk dalam rentang 2,60 - 3,39, berarti variabel kinerja karyawan dikategorikan cukup baik atau rata-rata responden menyatakan netral.

\section{c. Dimensi Variabel Kinerja} Karyawan (Y)

Terlihat nilai prediksi ratarata skor variabel kinerja karyawan sebesar 4,303. Nilai 4,303 masuk dalam rentang 4,205,00 , berarti variabel kinerja karyawan dikategorikan sangat baik atau rata-rata responden menyatakan sangat setuju.

\section{Uji Validitas}

Pendekatan yang dilakukan adalah menghubungkan suatu konstrak yang diteliti dengan konstrak lainnya yang dibentuk dari kerangka teoritik. Jika $r$ hitung $>r$ kritis, maka butir atau variabel tersebut valid, $r$ kritis sebesar 0,30 . Jika $r$ hitung $<r$ kritis, maka butir atau variabel tidak valid.

Dari tabel di atas masingmasing pertanyaan mempunyai nilai $r$ hitung lebih besar dari 0,30, berarti semua pertanyaan dari variabel lingkungan kerja, stres kerja, dan kinerja karyawan dinyatakan valid.

\section{Uji Reliabilitas}

Dengan uji reliabilitas ini berkaitan dengan konsistensi, akurasi dan prediktabilitas suatu alat ukur. Untuk $r$ hitung tiap item (variabel) bisa dilihat pada kolom cronbach alpha.

Nilai $r \quad 0,598$. Nilai 0,598 masuk rentang $0,57-0,74$, berarti tingkat reliabilitasnya dikategorikan cukup tinggi (cukup signifikan).

\section{Hasil Analisis Data Statistik} Interensial

\section{Analisis Regresi Linear Berganda}

Rumus koefisien regresi linear berganda adalah $Y=8,882+$
0,799 $X_{1}-0,002 X_{2}$. Keterangan: $X_{1}$ adalah variabel lingkungan kerja; $X_{2}$ adalah variabel stres kerja; dan $Y$ adalah variabel kinerja karyawan.

Analisis regresi berganda sebagai berikut:

1. Nilai constant sebesar 8,882 menyatakan bahwa jika tidak ada variabel lingkungan kerja dan stres kerja maka nilai kinerja karyawan sebesar $8,882 \%$.

2. Koefisien regresi $X_{1}$ sebesar 0,799 menyatakan bahwa setiap penambahan $1 \%$ lingkungan kerja akan meningkatkan kinerja karyawan sebesar $0,799 \%$. Dengan ketentuan stres kerja $\left(\mathrm{X}_{2}\right)$ constant.

3. Koefisien regresi $X_{2}$ sebesar 0,002 menyatakan bahwa setiap penambahan $1 \%$ stres kerja akan menurunkan kinerja karyawan sebesar 0,02 \%. Dengan ketentuan lingkungan kerja $\left(\mathrm{X}_{1}\right)$ constant.

\section{Analisis Koefisien Korelasi}

Di bawah ini dipaparkan hasil uji koefisien korelasi persial dan korelasi simultan sebagai berikut

\section{a. Koefisien Korelasi Parsial}

Koefisien korelasi persial merupakan indeks atau bilangan yang digunakan untuk mengukur keeratan hubungan dan membuktikan hipotesis hubungan antara variabel independen dengan variabel dependen.

Hasil analisis berdasarkan tabel di atas dari hasil pengolahan SPSS 20 sebagai berikut:

1) Nilai koefisien korelasi ( $r$ ) variabel Lingkungan Kerja Nilai 0,909 berada dalam rentang $0,80-1,00$ berarti hubungan variabel lingkungan kerja 
dengan variabel kinerja karyawan dikategorikan sangat erat.

2) Nilai koefisien korelasi ( $r$ ) variabel Stres Kerja Nilai 0,099 berada dalam rentang $0,00 \quad$ s.d $-0,199$ berarti hubungan variabel stres kerja dengan variabel kinerja karyawan dikategorikan sangat lemah.

\section{b. Koefisien Korelasi Simultan}

$$
\text { Koefisien korelasi }
$$

berganda (multiple correlation) diberi symbol $\mathrm{R}$ adalah angka yang menunjukan arah dan keeratan hubungan dan membuktikan hipotesis hubungan antara variabel independen secara simultan atau secara bersama-sama dengan variabel dependen.

Hasil

analisis

berdasarkan tabel di atas dari hasil pengolahan SPSS 20 adalah nilai koefisien korelasi simultan $(R)=0,859$. Nilai 0,859 berada dalam rentang 0,80-1,00, berarti hubungan variabel Lingkungan Kerja dan Stres Karyawan secara simultan dengan variabel Kinerja Karyawan dikategorikan sangat erat.

1) Hasil Uji hipotesis 1: Pengaruh Lingkungan Kerja terhadap Kinerja Karyawan.

Nilai t hitung lebih besar dari atau $16,358>1,984$ dengan nilai signifikan $<0,05$ atau $0,000<0,05$ pada t tabel maka Ho ditolak, Ha diterima. Dengan demikian terdapat pengaruh yang signifikan antara lingkungan kerja terhadap kinerja karyawan pada RSPAD Gatot Soebroto.
2) Hasil Uji hipotesis 2: Pengaruh stres kerja terhadap kinerja karyawan.

Nilai -t hitung lebih besar dari atau $-0,34>-1,984$ dengan nilai signifikan $>0,05$ atau $0,973>0,05$ pada $t$ tabel maka Ho diterima dan Ha ditolak. Dengan demikian tidak terdapat pengaruh yang signifikan antara stres kerja terhadap kinerja karyawan pada RSPAD Gatot Soebroto.

\section{a. Hasil Uji F}

Uji statistik $F$ pada dasarnya menunjukan apakah semua variabel independen yang dimasukkan dalam model mempunyai pengaruh secara bersama-sama terhadap variabel dependen.

Nilai $\mathrm{F}$ hitung lebih besar dari $\mathrm{F}$ tabel atau 136,802 > 3,0902 sehingga $H_{0}$ ditolak. Dengan demikian $\mathrm{H}_{\mathrm{a}}$ diterima, yaitu ada pengaruh lingkungan kerja dan stres kerja secara simultan terhadap kinerja karyawan.

\section{Uji Koefisien Determinasi}

Analisis koefisien determinasi bertujuan untuk mengetahui persentase pengaruh variabel independen, yaitu: Lingkungan Kerja, dan Stres Kerja terhadap Kinerja Karyawan di RSPAD Gatot Soebroto.

Diketahui bahwa nilai koefisien $\mathrm{R}^{2}$ adalah sebesar 0,738 atau $73,8 \%$. Hal ini berarti bahwa $73,8 \%$ variabel kinerja karyawan dapat dijelaskan oleh ke dua variabel independen yaitu; lingkungan kerja dan stres kerja. Sedangkan sisanya $26,2 \quad \%$ dipengaruhi oleh variabel lain di luar penelitian.

\section{E. Pembahasan}

Penelitian ini menguji apakah 
lingkungan kerja dan stres kerja berpengaruh terhadap kinerja karyawan di RSPAD Gatot Soebroto.

\section{Pengaruh Lingkungan Kerja terhadap Kinerja Karyawan RSPAD Gatot Soebroto.}

Pada hasil Penelitian ini
variabel lingkungan kerja
menunjukan bahwa lingkungan kerja berpengaruh terhadap kinerja karyawan di RSPAD Gatot Soebroto. Hal ini semakin baik persepsi konsumen terhadap lingkungan kerja maka semakin tinggi kinrerja karyawan atau semakin buruk persepsi konsumen terhadap lingkungan kerja maka semakin rendah kinerja karyawan. Dengan hipotesis ini mempunyai penelitian yang telah terbukti kebenarannya. Hasil penelitian ini sesuai dengan yang dilakukan oleh peneliti.

2. Pengaruh Stres Kerja terhadap Kinerja Karyawan RSPAD Gatot Soebroto.

Hasil penelitian untuk variabel stres kerja berpengaruh terhadap kinerja karyawan RSPAD Gatot Soebroto. Berdasarkan penelitian ini, menjelaskan bahwa variabel stres kerja tidak memiliki pengaruh secara signifikan terhadap kinerja karyawan. Artinya semakin tinggi stres kerja maka semakin rendah kinerja karyawan atau semakin rendah stres kerja maka semakin tinggi kinerja karyawan, sehingga hipotesis dalam penelitian ini selalu terbukti dan benar. Hasil penelitian ini dilakukan sesuai dengan peneliti di RSPAD Gatot Soebroto.

\section{SIMPULAN DAN SARAN}

\section{A. Simpulan}

Analisis yang telah dilakukan dalam penelitian ini, dapat disimpulkan sebagai berikut:

1. Skor variabel lingkungan kerja sebesar 4,281. Nilai 4,281 masuk dalam rentang 4,20-5,00, berarti dimensi variabel lingkungan kerja dikategorikan sangat baik atau ratarata responden menyatakan sangat setuju.

2. Skor variabel stres kerja sebesar 3,309 . Nilai 3,309 masuk dalam rentang 2,60-3,39, berarti variabel stres kerja dikategorikan baik atau rata-rata responden menyatakan setuju.

3. Skor variabel kinerja karyawan sebesar 4,303. Nilai 4,303 masuk dalam rentang 4,20-5,00, berarti dimensi variabel kinerja karyawan dikategorikan sangat baik atau ratarata responden menyatakan sangat setuju.

4. Lingkungan kerja berpengaruh terhadap kinerja karyawan. Hal ini dibuktikan dari nilai $\mathrm{t}$ hitung $>\mathrm{t}$ tabel atau 16,358 > 1,984 sebesar 16,358. Sedangkan nilai koefisien korelasi $(r)$ variabel lingkungan kerja $=0,909$ berarti hubungan variabel lingkungan kerja dengan variabel kinerja karyawan dikategorikan sangat erat.

5. Stres kerja tidak berpengaruh terhadap kinerja karyawan. Hal ini dibuktikan dari nilai -t hitung < -t tabel atau $-0,34<-1,983$. Sedangkan Nilai koefisien korelasi (r) variabel stres kerja $=-0,099$ berarti hubungan variabel stres karyawan dengan variabel kinerja karyawan dikategorikan rendah.

6. Hasil dari analisis berdasarkan hasil pengolahan SPSS 20 yaitu ada pengaruh lingkungan kerja dan stres kerja secara simultan terhadap 
kinerja karyawan. Hal ini dibuktikan dari nilai $f$ hitung sebesar 136,802. Nilai koefisien korelasi simultan (R) $=0,859$. Nilai 0,859 berada dalam rentang 0,80-1,00, berarti hubungan variabel lingkungan kerja dan stres kerja secara simultan dengan variabel kinerja karyawan dikategorikan sangat erat signifikan. Sedangkan nilai koefisiensi determinasi (R2) sebesar 73,8 \%, berarti kontribusi variabel lingkungan kerja dan stres kerja secara simultan terhadap kinerja karyawan sebesar 73,8 \% sedangkan sisanya $26,2 \%$ adalah faktor lain yang tidak diteliti.

\section{B. Saran}

Berdasarkan hasil analisis pembahasan serta beberapa kesimpulan pada penelitian ini, adapun saran-saran yang dapat diberikan melalui hasil penelitian ini agar mendapatkan hasil yang lebih baik, yaitu:

1. Rumah Sakit sebaiknya melakukan penilaian periodik (sebulan sekali) dan terencana sehingga dapat diketahui apa saja yang perlu dilakukan oleh Manajemen Rumah Sakit dalam rangka meningkatkan kinerja karyawan.

2. Rumah Sakit perlu memperbaiki kebijakan-kebijakan dalam organisasi, peningkatan penggunaaan teknologi, meningkatkan kenyamanan yang menyangkut kondisi fisik tempat kerja yang menyenangnkan, dan juga menjalin kerja sama yang baik antar karyawan dan juga kryawan dengan atasan.

3. Pihak Rumah Sakit perlu melengkapi fasilitas, seperti area parkir yang besar, dan AC dalam ruangan untuk mempersejuk ruangan agar lebih nyaman. Karena dengan fasilitas dan lingkungan kerja yang baik akan menimbulkan kinerja yang baik pula sehingga mendorong para karyawan untuk lebih giat dalam bekerja.

4. Pihak Rumah Sakit memiliki unit yang mengelola SDM dan benarbenar peduli serta memperhatikan keadaan, kehidupan keluarga, dan tingkah lakunya dalam menjalankan pekerjaannya sehari-hari. Bila mulai terlihat ada keanehan ataupun hal yang tidak wajar, bagian SDM dapat memberikan pendekatan khusus terhadap karyawan dan membantu pemecahan permasalahannya.

\section{DAFTAR PUSTAKA}

Alex S, Nitisemito. 1992. Manajemen dan Sumber Daya Manusia. Yogyakarta: BPFE UGM.

Anoraga, Panji. 2001. Psikologi Kerja. Jakarta: PT Rineka Cipta.

Anwar Prabu Mangkunegara. 2000. Manajemen Sumber Daya Manusia Perusahaan. Bandung: PT Remaja Rosda Karya. Cetakan $\mathrm{Ke}-6$.

Arikunto, Suharsami. 2002. Prosedur Penelitian Suatu Pendekatan Praktek. Jakarta: PT Rineka Cipta.

Sunyoto, Ashar dan Munandar. 2001. Psikologi Industri dan Organisasi. Jakarta: UI Press.

Kusriyanto, Bambang. 1991. Meningkatkan Produktivitas Karyawan . Jakarta: PT Pustaka Binaman Pressindo. 
Bart, Smet. 1994. Psikologi Kesehatan. Jakarta: PT Gramedia Widiasarna Indonesia.

Cooper, Cary dan Straw, Alison. 1995. Stress Manajemen yang Sukses dalam Sepekan. Jakarta: Kesaint Blanc.

Gibson, et al. 1996. Organisasi, Perilaku, Struktur, Proses. Jakarta: Bina Rupa Aksara.

Gibson, James L. 1997. Organisasi. Jakarta: Erlangga.

Handoko, T. Hani. 1995. Manajemen. Yogyakarta: BPFE.

Igor, S. 1997. Pekerjaan Anda Bagaimana Mendaptkannya Bagaimana Mempertahankannya. (Alih Bahasa Monica). Solo: Dabara.

Indriani, Azizah. 2009. Pengaruh Konflik Peran Ganda dan Stres Kerja Terhadap Kinerja Perawat Wnita RS Roemani Muhammadiyah. Semarang.

Intan Prima Prestiyana. 2008. Pengaruh Stres Kerja terhadap Kinerja Karyawan: Studi Kasus Karyawan Foodmart Ekalokasari Bogor. (Skripsi). Bogor: IPB.

Jacinta, F. 2002. Stres Kerja. www.epsikologi.com di akses tanggal 20 Desember 2018.

Linda Prasepti. 2003. Pengaruh Lingkungan Terhadap Kinerja Karyawan Produksi. Surabaya: PT. Surya Sakti Utama.
Prabu, Mangkunegara Anwar. 1993. Psikologi Perusahaan. Bandung: PT Trigenda Karya.

-----.. 2001. Manajemen Sumber Daya Perusahaan. Bandung: PT Remaja Rosdakarya.

Mirzatriana, Merina. 2008. Pengaruh Faktor-Faktor Stres Kerja terhadap Kinerja Karyawan Bidang Keuangan Pada PT PLN (Persero) Distribusi Jawa Timur. (Skripsi). Semarang: Universitas Diponegoro.

Wulandari, Nita Wahyu. (2006). Pengaruh Stres Kerja Terhadap Kinerja Pegawai.

Nurdyansyah, Deden. 2009. "Pengaruh Budaya Perusahaan dan Lingkungan Kerja terhadap Kinerja Pegawai". Jurnal Telaah Manajemen Vol.3 Edisi 1.

Prawirosentono, S. 1999. Manajemen Sumber Daya Manusi, Kebijakan Kinerja Karyawan. Jakarta: Rineka Cipta.

Sedarmayanti, 2001. Sumber Daya Manusia dan Produkivitas Kerja. Bandung. Mandar Maju.

Silaen, Sofar dan Widiyono. 2013. Metodologi Penelitian Sosial untuk Penulisan Skripsi dan Tesis. Jakarta: In Media.

Sugiyono. 2009. Metode Penelitian Pendidikan Kualitatif Kuantitatif dan $R \& D$. Bandung: Alfabeta.

-----.. 2012. Statistika untuk Penelitian. Bandung: Alfabeta. 
JMB Jumal Manajemen \& Bisnis Jayakarta
p-ISSN : xxxx-xxxx

e-ISSN : xxxx-xxxx

Vol. 01, No. 1, Juli 2019 
